\title{
North Korea, Nuclear Weapons, and No Good Options? A Controlled Path to Peace
}

\author{
Michael D. Cohen
}

\begin{abstract}
How would North Korea's development of the capability to target the United States with nuclear weapons influence its foreign policy? I argue that it would cause more dangerous crises than those of the last decade, and predict that these crises would eventually cause Kim Jong Un and his senior military associates to experience fear of imminent nuclear war or conventional regime change. I show that the effect of such fear would depend on whether or not Kim believes that he has control over the occurrence of these events. I argue that if he experiences fear and believes that he has some control over whether these extreme events actually happen, he will moderate his nuclear threats and behave more like other experienced nuclear powers. But if he experiences fear and believes that he has no control, he will likely pursue policies that could cause nuclear war. I use this insight to prescribe and proscribe policies for Washington, Seoul and the regional community.
\end{abstract}

Keywords North Korea, nuclear proliferation, nuclear deterrence, nuclear compellence/coercion, U.S. foreign policy, South Korea, alliances, social psychology

\section{Introduction}

How would the capability to target the United States with nuclear missiles influence North Korean foreign policy? What might the United States, South Korea and the regional community do to prevent the worst outcomes and encourage desirable ones? In this article I shall address these questions and argue that Kim's personal experience of fear of imminent nuclear war in what I shall argue is an inevitable nuclear crisis-if Pyongyang develops the aforementioned capability-will largely determine whether nuclear war erupts on the Korean peninsula.

While Pyongyang's persistence with its nuclear program in defiance of international sanctions and its growing isolation seem designed to achieve a nuclear arsenal capable of targeting the U.S. mainland, it is far from clear

(C) 2013 The Institute for Peace and Unification Studies, Seoul National University

ISSN 2288-2693 Print, ISSN 2288-2707 Online 
that it will be realized, and I do not address that question here (Hymans 2006; Solingen 2006). However, it is also unclear how such a capability would influence Pyongyang's behavior. The question of how nuclear proliferation influences a state's conflict propensity has received extensive theoretical (Waltz and Sagan 2013) and empirical (Horowitz 2009; Gartzke and Jo 2009; Beardsley and Asal 2009a; 2009b; Gartzke 2010) treatment. However, exactly how nuclear weapons influence the behavior of new nuclear powers remains unclear (Feaver 1995, 769; Karl 1997, 118; Montgomery and Sagan 2009, 321; Jervis 2009, 212). The potential destruction that nuclear war would involve could encourage moderation, but it could also cause revisionism precisely because the destruction of nuclear war makes war unlikely (Snyder 1965, 199). It is also possible that because North Korean policy is already so undesirable, nuclear weapons capable of targeting the United States will change little of Pyongyang's behavior (Gartzke and Jo 2009).

I do not extensively detail the history of the North Korean nuclear program, efforts by the United States, South Korea and their allies to curtail it, nor Pyongyang's recent provocations. Rather, I provide a theoretical prediction of how North Korea would behave after developing deliverable nuclear weapons that is grounded in realist theory and social psychology (Jervis 1976; Khong 1992; Mercer 1996; Reiter 1996). I make four arguments. First, North Korea has been practicing nuclear compellence. Second, developing the capability to target the United States with nuclear missiles would likely cause more of the same behavior, much of which would likely be more dangerous. Third, nuclear compellence tends not to realize revisions to the status quo, and actually tends to cause nuclear crises, at least when practiced by new nuclear powers. Finally, the danger posed by a North Korean nuclear missile capability would depend on whether Kim Jong Un, and/or the other generals or military officials responsible for the use of nuclear weapons, experience fear of imminent nuclear war or regime change, and believe that they have some control over whether nuclear war actually occurs. By control, I do not refer to that which Kim might have over the bureaucracy, military or even diplomacy, but rather the simple belief that he can or cannot control whether nuclear war occurs amidst a nuclear crisis. By nuclear crisis, I refer in this context to a crisis more dangerous than those which have already occurred on the Korean peninsula. I shall argue that if the North Korean leaders experience fear of imminent nuclear war or regime change, and believe that they have some control over whether these events occur, they would refrain from nuclear compellence and behave more like other experienced nuclear powers. Even so, however, Pyongyang will be unlikely to give up its nuclear weapons and may continue to provide sensitive nuclear assistance to other parties (Kroenig 2010; Fuhrmann 2012). On the other hand, if the leaders experience fear of imminent nuclear or conventional war and believe that they have no control over whether it occurs, they may use nuclear weapons in a last bid either to save the regime or to inflict some damage on Seoul and the United States. I conclude 
with implications of this analysis for policy prescriptions and proscriptions for the United States, South Korea and the regional community to realize a peaceful Korean peninsula.

Importantly, because I am predicting the behavior of North Korea after Kim achieves a qualitatively distinct technological breakthrough that he has not yet realized, past North Korean behavior tells us little about future behavior when Pyongyang can target the United States with nuclear missiles. The ability to target one's primary adversary with nuclear weapons is revolutionary, especially if one has a survivable second strike arsenal. So, North Korean behavior before achieving this milestone should be different from its behavior after having done so (Jervis 1989; Waltz 1990). Because North Korea has yet to achieve this breakthrough, and evidence on the beliefs of North Korean leaders is elusive, I support my claims through a combination of case studies and quantitative evidence from other nuclear power cases and, in the case of fear, from experimental studies with randomly selected Americans. Those who believe that we can learn nothing about North Korea from the experiences of new nuclear powers in the Cold War, China, and South Asia will find little of interest here. I submit that while North Korea is obviously unique in many important ways, we can learn a lot about how Pyongyang would behave when it can target the United States with nuclear weapons from a careful reading of the historical record.

\section{Nuclear Compellence Rarely Works}

Thomas Schelling (1966) long ago differentiated between deterrence and compellence. Deterrence involves threats to respond, usually with retaliation, to challenges to the status quo. Compellence involves threats to respond with retaliation to the continuation of the status quo: the threat is directed to an actor to stop some action that he has already begun or to initiate an action that he has thus far refrained from doing (Schelling 1966; Byman and Waxman 2002). When both states have nuclear weapons, compellence tends to be harder than deterrence (Jervis 1989, 28-32). Nuclear weapons make conflict costly; so insofar as challenges tend to increase the probability of war, nuclear weapons reinforce the status quo. While deterrence is aimed at maintaining the status quo, compellence aims to revise it. Deterrent threats force one's adversary to make the first move amidst uncertainty that the defender will retaliate and that this retaliation could cause undesired escalation. Compellent threats require the compeller to move first and risk nuclear escalation because the adversary defies the threat by inaction. Because moving first and challenging the status quo is dangerous, nuclear deterrence is usually easier than nuclear compellence. Finally, because both sides have lived with the status quo for a while, threats to do something that might cause nuclear war if it is maintained are less credible than 
threats to move closer to nuclear escalation if it is revised. Pyongyang has lived with an unfavorable status quo for 60 years. One might argue that the end of the Cold War presents new challenges because sources of Soviet and Chinese support have dried up; but the Cold War ended 15 years ago. North Korean threats to revise an intolerable status quo under the threat of potential nuclear escalation lack credibility because of the simple fact that Pyongyang has lived with the postCold War status quo for 15 years and the general status quo for 60 years.

Quantitative and qualitative evidence supports the claim that nuclear compellence tends not to cause revisions to the status quo. Sechser and Fuhrmann (2013) analyzed a series of compellence threats from 1918 to 2001 and found that nuclear compellence threats cause desired revisions in about $20 \%$ of cases, a figure that is less than the success rate of conventional compellence threats. McGeorge Bundy (1988) offered a more detailed qualitative assessment of nuclear compellence in the Cold War and found little evidence that it revises the status quo. Nuclear weapons did not allow Mao Zedong to revise territorial boundaries with the Soviet Union in the disputed Ussuri River region in the late 1960s. Pakistani nuclear weapons have not allowed a revision of the Kashmir division on Pakistani terms; and Indian nuclear weapons have not stopped terrorists based in Pakistan from occasionally attacking India.

For over a decade, North Korea has used nuclear and missile tests to unsuccessfully compel the United States to formally end the 1950-53 Korean war, grant it diplomatic recognition and end its political and economic isolation. Pyongyang's nuclear weapons have reinforced deterrence against aggression directed at North Korea and the subversion of Kim's regime. But Pyongyang has been practicing nuclear compellence rather than, or at least as well as, nuclear deterrence, in two senses. While deterring threats to the regime appears at first to be deterrence, it can also be viewed as compellence because the status quo is moving against North Korea. Over time Pyongyang's economy will grow even weaker relative to South Korea's, leaving Seoul with the potential to develop vastly stronger conventional military power. As global information flows become faster and more interconnected, Pyongyang has to ensure that North Koreans prefer the little they have over the riches that they will inevitably see elsewhere. These trends will not decrease over time. Economic migrants working in China, legally or illegally, return to the North with news from the outside. Radio broadcasts by Voice of America and Radio Free Asia can be picked up in North Korea near the Chinese border and perhaps throughout the country. South Korean movies, videos, and music, the possession of which can be severely punished, are constantly brought and smuggled into North Korea. South Korean nongovernment organizations often float balloons into North Korea with packages of Chinese food, currency and newspapers. Threats to respond to undesirable behavior with a "sea of fire" are about not only deterring aggression against Pyongyang but also restraining the global forces that promise to eventually 
undermine North Korea. Pyongyang's strategy of seeking negotiated resolutions with the United States on its own terms through calculated brinksmanshipa strategy very similar to Khrushchev's Soviet Union-is fundamentally about revising the status quo and a clear case of nuclear compellence. North Korea has been practicing nuclear compellence for over a decade, but it has not realized Pyongyang's revisionist goals.

As of December 2011, North Korea may have amassed enough enriched uranium for between four and seven nuclear weapons, and enough plutonium for about 12 weapons (Albright and Walrond 2012). Pyongyang's recent challenges have been especially dangerous. The March 2010 sinking of the South Korean corvette Cheonan killed 46 South Korean seamen, and the December 2010 firing of 180 artillery shells on the South Korean island of Yeonpyeong killed two South Korean marines, two local construction workers, injured 19 and destroyed dozens of properties. These two strikes have constituted the most serious conventional military attack by North Korea on South Korea since an attempted commando raid on the South Korean presidential palace in 1968. Perhaps more tellingly, Victor Cha found that every North Korean provocation for the past 30 years has been followed within about six months by a period of dialogue and negotiations where Pyongyang has gained some concession (Cha 2008, 237). The October 2006 first nuclear test led to international condemnation and United Nations Security Council sanctions but also prolonged negotiations with the United States. When Pyongyang launched its three-stage Taepodong-I ICBM in 1998 over Japan, the Clinton administration hosted missile talks with the North in New York within two months. Kim Jong Il and Kim Jong Un have surely learned that nuclear compellence will realize negotiations with the United States. Nuclear weapons have destabilized the Korean peninsula because Kim and his associates have likely learned that North Korean nuclear missiles able to target the United States might allow further threats and uses of force to generate sustained revisions to the status quo.

The historical record suggests that Kim will keep practicing nuclear compellence until he experiences fear of imminent nuclear war. I have argued at greater length elsewhere that when nuclear powers desire revisions to the status quo and issue a series of nuclear compellence threats to achieve them, the experience of fear of imminent nuclear war is necessary to moderate their revisionism (Cohen 2013). Nikita Khrushchev, who was largely responsible for Soviet foreign policy during the Cold War crisis years of 1958-1962, issued three separate threats to remove the U.S. and allied presence in West Berlin and revise the German status quo (Fursenko and Naftali 1996; 2007; Taubman 2003). He persisted with the strategy after its failure to achieve U.S. concessions in 1959 and 1961. He refrained from issuing further challenges after deploying nuclear missiles to Cuba and the Cuban Missile Crisis. One might argue that the Cuban Missile Crisis was about defensive goals in Cuba while the Berlin crises were 
about revisionist goals in Berlin, but much evidence shows that Khrushchev also had revisionist Berlin objectives in mind when he authorized such a large offshore missile base in Cuba. However, Khrushchev refrained from challenging the status quo after experiencing fear of imminent nuclear war. A systematic search of Soviet archival material and the primary and secondary literature on Khrushchev and the Cold War crises revealed no evidence that he experienced fear of imminent nuclear war earlier than October 24, 1962 (Cohen 2013).

Mao Zedong challenged Soviet troops on Zhenbao Island in the Ussuri River in the years after developing nuclear weapons in 1964. The last skirmish occurred in 1969, just before the war scare when Mao was so worried about a Soviet strike that he ordered his entire government and army to retreat from Beijing for the countryside (Kuisong 2000). Pakistan has long aimed to revise the status quo in Kashmir: the 1948, 1965 and 1999 wars were all fought in large part over this region. Although the role of the Pakistani government in the October 2001 attacks on the Indian parliament and the May 2002 attacks on Indian civilians at the Jammu military base remains unclear, it seems certain that then President Musharraf experienced fear of imminent nuclear war on May 30 and 31, 2002 (Cohen 2013). Pakistani nuclear threats have largely ceased since then, and violence in Kashmir has substantially declined, although not disappeared. Musharraf and Mao do not appear to have experienced fear of imminent nuclear war before 1969 and 2002 respectively. Pyongyang has persisted with nuclear compellence policies that have caused several crises that do not seem to have caused Kim Jong Il or Kim Jong Un to experience fear of imminent nuclear war. There are strong reasons to suspect that Kim Jong Un will continue to pursue his nuclear compellence policy of calculated brinksmanship until he experiences fear of imminent nuclear war.

If six to ten nuclear warheads-that may not be able to be mated with medium and long range missiles-have caused the North Korean brinksmanship of the last decade, the ability to target the United States with nuclear weapons would likely cause at least more of the same, and perhaps even more dangerous, behavior. Kim Jong Un and his senior army generals likely believe that their existing small arsenal has increased their chances of revising their undesirable status quo. The current capability was sufficient for Kim, having tested a long range missile and conducted North Korea's third nuclear test, to threaten to attack South Korea and U.S. military bases in Japan and Guam, to withdraw from all non-aggression pacts with South Korea, place two North Korean Musudan missiles on high alert and shut down the Kaesong Industrial complex, one of the last remaining vestiges of cooperation with Seoul. Kim Jong Il periodically engaged in similar behavior. If North Korea's current force was sufficient to embolden Kim to engage in this behavior, the development of the capability to reliably target the United States with nuclear weapons should cause either more of the same or perhaps even more dangerous behavior. 
The United States and South Korea have thus far not conceded to Pyongyang's demands, and it is unlikely that greater North Korean nuclear capabilities will compel them to do so. Enhanced North Korean nuclear missile capabilities will not translate into a greater likelihood of compellence threats sustaining revisions to the status quo. If Pyongyang issues demands for bilateral negotiations with the United States after, say, testing a nuclear-capable missile that detonates off the coast of Hawaii, Washington can and will likely make no conciliatory moves. Washington would be much more likely to structure a response that signals not only that concessions are not forthcoming but that further provocative behavior would not be tolerated. U.S. forces in South Korea might be put on high alert, B-2 bombers might make flights over Pyongyang, and Kim would likely be told that any nuclear missile that hits the U.S. mainland would be met with a devastating attack on Pyongyang. Washington may threaten to destroy further nuclear missiles on their launchpads. The likely outcome of all of this is that Kim would cause a nuclear crisis more serious than previous ones-one in which he will experience fear of imminent nuclear war. He might worry that a U.S. attack is imminent even though the nuclear missile did not reach Hawaii, or might fear that Washington is no longer willing to put up with his brinksmanship and is willing to risk nuclear war to destroy his regime.

\section{Fear, Risk, and Control}

Fear is central to much of international politics (Tang 2008). According to the standard theoretical set-up-in which there is no international authority with the capability to enforce bargains between states and thus reveal the true balance of power and resolve-states that desire survival at a minimum and increased power at a maximum, but are also unable to credibly commit to agreements, introduce a large role for fear (Thucydides 1954; Jervis 1978, 172; Blight 1990; Mearsheimer 2001, 42-3). Uncertainty regarding whether states will be content with security or desire more power, whether they will abide by an agreementsay not to develop nuclear weapons or use force-leaves a large role for fear in world politics. The presence of nuclear weapons may increase the costs of conflict and levels of fear (Waltz 2003, 154). Leaders may fear that others will cheat on agreements not to develop nuclear weapons or not to provide them or related infrastructure to third parties. They could entertain a healthy fear that any crisis could escalate to nuclear war, or believe that nuclear war is imminent even if it is not (Johnson and Tierney 2011). While few would argue with the claim that fear is central to international politics, especially in the nuclear age, no scholarship has addressed whether variation in levels of fear causes variation in policies. Nor has anybody applied such a psychological framework to the consequences of nuclear proliferation. Recent experimental research however offers clear predictions for 
the effect of fear on leaders' acceptance of risk.

The human brain has evolved a dual process information processing system to deal with threats to survival (Damasio 1996; McDermott 2004). The brain constantly scans the environment for potential threats and if none are detected, the system responsible for more complex calculations drives behavior. But if a threat is detected, the brain automatically shuts down the higher order system and gives precedence to a more simple system that makes very quick fight-orflight decisions. Once the brain perceives that the threat has evaporated the higher order system is again given precedence; but stimuli that are perceived as similar to any earlier ones that caused fear will give precedence to the more simple system that may make decisions similar to those made when fear was earlier experienced (Rosen 2005, 27-70).

Jennifer Lerner and Dacher Keltner $(2000 ; 2001)$ have shown that fear has systematic effects on people's orientation to risk that is conditional on beliefs about control (Lerner et al. 2003). If people believe that they have a moderate level of control over the source of their fear-greater than zero but less than full control-the experience of fear causes them to avoid risk. However, beliefs about either total or no control reduce the effect of fear on risk. The treatment to manipulate fear used in their experiments was images of snakes and the destruction of September 11 that are known to induce fear (Smith and Ellsworth 1985). But the ethics requirements to conduct these experiments stipulate that this effect of fear should wear off within hours or probably minutes. The effect of the fear of imminent nuclear war should produce much greater impact on risk. Moreover, the experience of fear of imminent nuclear war when one believes that they have genuine control over whether nuclear escalation occurs-the condition when the effect on risk acceptance should be greatest-cannot be replicated in the laboratory. The effect of emotions on financial decision-making, where actors have similarly strong incentives to behave rationally, is also strong (Lee and Andrade 2011). Other research has shown that sufficiently strong experiences of fear can cause psychological conditions that last a lifetime (Tooby and Cosmides 2010, 119). There are, therefore, strong reasons to expect the experience of fear of imminent nuclear war, conditional on beliefs about control, to have significant effects on a leader's attitude toward risk.

The experience of fear of imminent nuclear war need not cause risk aversion because nuclear war is always extremely undesirable. Moreover, it is not clear that fear of imminent nuclear war would cause leaders to revise their estimates of its probability. Rather, because nuclear compellence raises the risk of inadvertent nuclear escalation, the experience of fear of imminent nuclear war, conditional on beliefs about control, should cause them to refrain from practicing nuclear compellence. While little in international politics is risk free, refraining from nuclear compellence will tend to reduce the risk of nuclear war.

Moreover, in authoritarian states where the pool of leaders is centralized 
and small, potential successors to leaders who cause a nuclear crisis may also have experienced fear of imminent nuclear war. There are thus strong reasons to believe that the leaders' experience of fear of imminent nuclear war will cause revisionist states to refrain from nuclear compellence and accept the status quo. If these leaders or their successors begin to make progress by addressing their objectives through confidence building measures, diplomacy and institutionalized cooperation, later generations may face incentives to refrain from the dangerous nuclear compellence that their predecessors practiced.

The authorization to use nuclear weapons in authoritarian states usually resides solely with one leader. They should therefore believe that they have control over whether a crisis occurs or whether it escalates to nuclear war. The Soviet troops operating the tactical and intermediate nuclear weapons in Cuba had to receive permission from Moscow to use nuclear weapons. While permission to use tactical nuclear weapons may have been delegated to commanders in the field during the 10-month South Asia crisis in 2001-2002, Pervez Musharraf likely believed that he had a substantial amount of control over whether nuclear war occurred. The experience of fear of imminent nuclear war should reduce the acceptance of risk under these conditions.

Khrushchev experienced fear of imminent nuclear war on October 24 or 25, 1962. The Soviet leader admitted to his colleagues on October 25 that we "started out and then got afraid" (Fursenko and Naftali 2006, 484). A Soviet deputy foreign minister told his colleagues that Khrushchev "shit his pants" when he heard that the U.S. Strategic Air Command was moving to DEFCON-2 (Dobbs 2008,112 ). Khrushchev admitted weeks later that "I was frightened about what could happen to my country or your country or all the other countries that would be devastated by a nuclear war" (Cousins 1972, 46). The Cold War did not end after the Cuban Missile Crisis, but from 1963 it exhibited much less danger.

Mao engaged in several skirmishes in the five years following China's development of nuclear weapons, but after experiencing fear of imminent war Sino-Soviet skirmishes in the Zhenbao area permanently stopped. Although there is no direct evidence that Mao experienced fear of imminent nuclear war, clearly a war scare occurred in 1969 (Kuisong 2000; Lewis and Xitai 2008). There is less evidence available in the Pakistani case, but on May 30 and 31, 2002, Pervez Musharraf experienced fear of imminent nuclear war. He apparently "hardly slept" because he "feared nuclear war" (Cohen 2013). Violence in Kashmir did not disappear after this but it did substantially decline (Kapur 2007; 2008). Also, it is possible that Musharraf's experience of fear caused the decline in Pakistani revisionism in Kashmir. It is not clear that the 2008 Mumbai attacks were sponsored by the Pakistani government. The Lakshar-e-Taiba may have taken over operational control of what may have been designed to be a much smaller operation by the Pakistani Army (Tellis 2009; Burke 2010).

North Korea is different in many ways from the Soviet Union, China and 
Pakistan, but these cases suggest that when revisionist leaders challenge the status quo, it may cause a nuclear crisis while believing that they have some control over whether or not nuclear war occurs, they refrain from nuclear compellence, moderate their foreign policies and accept earlier untenable status quos. Khrushchev, Mao and Musharraf held immense power in autocratic regimes. If Kim Jong Un experiences fear of imminent nuclear war and believes that he has some control over whether it occurs, he will probably behave similarly.

But leaders of nuclear powers may experience either fear of imminent nuclear escalation or conventional destruction and believe that they have no control over whether it occurs. If their conventional military power is significantly weaker than their adversary, fear of imminent regime change or of conventional war may have similar effects as that of fear of imminent nuclear war. Fidel Castro did not have control over the nuclear weapons in Cuba. Therefore, he would probably have believed that he had little control over whether nuclear war or regime change occurred; he would have believed that only Khrushchev and Kennedy had this authority. On October 27, 1962, Castro anticipated an "almost inevitable" U.S. invasion in the next "24-72 hours" (Cold War International History Project 2012, 327). He wrote to Khrushchev that if U.S. forces invaded Cuba, the Soviet Union should "eliminate such danger forever through an act of clear legitimate defense, however harsh and terrible the solution would be." In 1992 Castro said that during the crisis, if the United States had invaded, "I would have been ready to use nuclear weapons... [B] efore having the country occupied-totally occupied-we were ready to die in defense of our country." (Blight et al. 1993, 252, 481). It is not clear that if Castro expected a devastating conventional or nuclear war, but he believed that the destruction of his regime was imminent, that nuclear war was likely or imminent, and that there was little that he could do to prevent it. Castro's high level of risk acceptance has often been attributed to ideology or personality, but it is explained by the simple fact that he experienced fear of imminent destruction and believed that he had no control over it.

This variation in response to fear of imminent nuclear war and/or destruction offers important predictions of North Korean behavior. If Kim Jong Un experiences fear of imminent nuclear or conventional war and believes that he has some control over whether it occurs, subsequent North Korean behavior will be less dangerous. Kim will likely issue fewer nuclear compellence threats and behave like other experienced nuclear powers. If he experiences such fear and believes that he has no control, he may use nuclear weapons in a final bid to save his regime or ensure that South Korea and the United States also sustain serious damage.

It is worth noting that provoking a crisis to cause Kim to experience fear of imminent nuclear war would be a bad idea because he would correctly believe that he had no control over it. He could not know that the intent was 
only to cause a crisis rather than a war or regime change, and would, given his conventionally weak military position, likely, and probably correctly, believe that he had little control. A large part of why North Korean nuclear brinkmanship is so dangerous is North Korea's relative weakness. If Kim experiences fear of imminent nuclear war or conventional destruction he may be highly likely to believe that he has no control over whether it occurs. Kim may believe that Washington desires an end to his regime, and may have learned from the 2003 Iraq war and 2011 Libya intervention that the United States is willing to invade North Korea if Pyongyang's nuclear weapons could be neutralized. Like Castro, his weak conventional power would leave him with little control over any conflict with the much more powerful United States and South Korea. If Kim genuinely believed that Washington or Seoul had initiated a crisis or were about to engage in an imminent preventive or pre-emptive attack, he would (rightly) believe that he had little control over escalation and faced the possibility of the destruction of his regime. Ironically, if North Korea was a stronger military power, Kim might believe that he had more control over a potential military confrontation. The very weakness that has driven Pyongyang's quest for the bomb also leaves Kim prone to the preferences that caused the most dangerous part of the Cuban Missile Crisis.

The desired effects of the experience of fear of imminent nuclear war seem most likely to be brought about by unprovoked North Korean challenges. I have argued that this is precisely the sort of behavior that the capability to target the United States with nuclear weapons would embolden Kim to pursue. He would likely believe that he has more control over whether nuclear war occurs in such a scenario than one in which Washington or Seoul made the first move. If he believed that his actions caused escalation, he would likely believe that his actions might also de-escalate the crisis, as they have in the crises that have followed North Korea's three nuclear tests. The United States, South Korea and the international community need to ensure that when a more serious nuclear crisis on the Korean peninsula causes Kim Jong Un to experience fear of imminent nuclear war-and it is almost guaranteed if Kim develops the capability to target the United States with nuclear weapons-he believes that he has control over whether war occurs and that he does not come to believe that a U.S. strike is imminent. This trade-off raises complex policy challenges.

\section{Policy Challenges}

One trade-off can be dismissed fairly quickly: If North Korea develops the capability to target the United States with nuclear missiles, Seoul and Washington will have to live with it. They should not develop plans to destroy Pyongyang's nuclear arsenal because identifying the location of every weapon would be 
very difficult. In a regime that we know so little about that it took almost nine hours for Seoul to learn of Kim Jong Il's death, it is not realistic to assume that Washington, Seoul and their allies can identify the location of each nuclear weapon. A preventive strike on North Korea that did not destroy all North Korea's nuclear weapons would likely cause Kim to believe that he had little control, and so retaliate on Seoul and/or U.S. bases in the region with his remaining nuclear weapons.

If Kim develops the capability to target the United States with nuclear weapons and engages in a series of more provocative crises, leaders in Seoul and Washington will have to decide whether they would prefer that he experience fear in the short term-with the associated risk that he may believe that he has no control-or aim to ensure that he never experiences fear of imminent nuclear war. The risks associated with his belief in no control suggest that the latter may seem more desirable. But once Kim can target the United States with nuclear missiles, the frequency and boldness of his nuclear compellence threats will increase. Unless Washington grants him the diplomatic and economic concessions that he seeks - which is unlikely and perhaps undesirable if he and other states learn that nuclear threats will eventually gain concessions-South Korea and the United States will have to find a way to respond to his challenges and defend themselves. But defending Seoul from North Korean aggression gets back to the problem of Kim's fear of imminent destruction and his belief in lack of control.

Seoul and especially Washington need to credibly assure Kim that they have no intention of destroying his regime in peacetime or during a crisis. While President Obama has stated that all options are on the table with regards to Iran and North Korea, he would do well to unilaterally renounce any U.S. moves toward Tehran, Pyongyang or elsewhere aimed at regime change. Any targeted military strikes against Pyongyang would likely be perceived by Kim as signs of imminent regime change over which he has no control. Seoul and Washington need to calibrate a response to North Korean aggression that does not allow Pyongyang to revise the status quo, but which does not cause Kim to believe that he has lost control of a crisis. They need to coordinate policies that prevent North Korea from sustaining revisions to the status quo but ensure that Kim always believes that he can de-escalate the crisis. Destroying North Korean missiles on the launchpad or in North Korean airspace might convince Kim that another attack on North Korean soil is imminent. But stating that any nuclear missiles will be destroyed once they approach South Korean, Japanese or U.S. airspace might deter Kim from these flight paths and reassure him that his adversaries' intentions are more defensive than offensive. If nuclear-armed missiles are to be destroyed on the launchpad, Washington and Seoul have to clearly communicate to Pyongyang that missiles without nuclear payloads will not be destroyed, and that further use of force will not be forthcoming.

To credibly commit that Washington does not intend to strike Pyongyang, 
the United States might draw down troops in South Korea to numbers with an operational capability to defend Seoul from North Korean challenges but insufficient to engage in longer term combat. This might signal to Pyongyang that Washington does not wish to engage in regime change in North Korea and only wishes to maintain the status quo. A reduced U.S. role in organizing and implementing responses to North Korean provocations might teach Pyongyang that Seoul and Washington do not have offensive ambitions.

It is also possible that once North Korea can target the United States with nuclear missiles, Pyongyang will engage in more aggressive behavior than the Yeonpyeong and Cheonan incidents. If Seoul were to retaliate, careful signals must be sent to Pyongyang to the effect that Seoul is only defending South Korean vessels and maintaining the status quo and does not plan to push further into North Korean territory. Ideally, these maneuvers would be conducted with vessels that Pyongyang understands to be best suited to defensive objectives. Retaliation against North Korean forces should be conducted by those forces ill-suited to an invasion of North Korea.

Some might bemoan the fact that these policies effectively accept North Korea as a nuclear power. This conclusion is right and wrong. It is right insofar as it rejects arguments that claim that striking Pyongyang now is the best of a bad set of options, as well as its assumption that there are no ways of convincing North Korea to give up its nuclear weapons. It finds company in other work that argues that North Korea is unlikely to give up nuclear weapons and that we should focus on preventing Pyongyang from exporting its nuclear know-how and preventing inadvertent escalation on the Korean peninsula (Acton 2013). This conclusion is wrong in that it overlooks the fact that powerful economic, political and technological forces will eventually undermine North Korea if military force does not. The forces that isolate North Korea threaten to undermine the Kim dynasty. Ensuring that Kim experiences fear of imminent nuclear war, if he develops the capability to target the United States with nuclear weapons, and believes that he has control over his country's fate, will ensure that the road to peace and unification is not marked by nuclear war. Regime collapse short of the use of military force may require Washington and Seoul to credibly commit to Kim and his associates that he has control over his future. If he believes that he will die, he may authorize the use of nuclear weapons. The South Korean development of nuclear weapons might influence the probability of a nuclear crisis on the Korean peninsula but will not alter the fundamental psychological logic outlined above. China's aid to North Korea and its debatable influence over Pyongyang's nuclear program would also not mitigate the psychological logic.

The United States has maintained military operational control over South Korean forces since the Korean war. While Seoul assumed peacetime control in 1994, the United States is still obliged to lead South Korea's military in the event of war. South Korea was due to take over this role in 2012, but North Korean 
provocations caused this date to be pushed back to December 2015. South Korean defense minister Kim Kwan-Jin recently stated to a parliamentary defence committee of the South Korean National Assembly that "considering the third nuclear test and the situations from March to May, the December 2015 deadline is not appropriate" (Kim 2013). In the weeks after North Korea's third nuclear test, U.S. Air Force B-52 and B-2 stealth bombers flew on roundtrips over the Korean peninsula where the latter dropped inert munitions on a South Korean bombing range (Dudley 2013). Pentagon officials called this mission a clear demonstration of "the United States' ability to conduct long range, precision strikes quickly and at will." South Korean President Park Geun-Hye claimed, in October 2013, that she would seek highly accurate anti-WMD capabilities from the United States and/or interoperability with U.S. systems that enable pre-emptive strikes on North Korean missile and nuclear sites (Yonhap News October 1, 2013; Lee 2013). It is hard to imagine how the United States can credibly commit to leave Kim with the belief that he has some control over the fate of his regime amidst a nuclear crisis without handing over operational control of U.S. forces in South Korea to Seoul and substantially reducing the U.S. military forces on the Korean peninsula. All of this will likely require humility in Washington and an acceptance of the limitations of U.S. power. Similarly, Seoul will need to take a more independent role in engaging North Korea. While nuclear proliferation on the Korean peninsula has become dangerous because Kim has learned that nuclear compellence works, it will become safer if Kim experiences fear of imminent nuclear war in a crisis and believes that he has control over nuclear escalation.

\section{References}

Acton, James A. 2013. "Focus on Nonproliferation-Not Disarmament-in North Korea." Carnegie Endowment for International Peace, February 14. http://carnegieendowment. org/2013/02/14/focus-on-nonproliferation-not-disarmament-in-north-korea/fgl5 (accessed July 30, 2013).

Albright, David, and Christina Walrond. 2012. "North Korea's Estimated Stocks of Plutonium and Weapon Grade Uranium." Institute for Science and International Security Report. August 16. http://isisonline.org/uploads/isisreports/documents/ dprk_fissile_material_production_16Aug2012.pdf (accessed October 24, 2013).

Beardsley, Kyle, and Victor Asal. 2009a. "Nuclear Weapons as Shields." Conflict Management and Peace Science 26 (3): 235-55.

Beardsley, Kyle, and Victor Asal. 2009b. "Winning with the Bomb." Journal of Conflict Resolution 53 (2): 278-301.

Blight, James G. 1990. The Shattered Crystal Ball: Fear and Learning in the Cuban Missile Crisis. Maryland: Rowman and Littlefield.

Blight, James G., Bruce J. Allyn, and David A. Welch. 1993. Cuba on the Brink: Castro, the 
Missile Crisis, and the Soviet Collapse. New York: Pantheon.

Bundy, McGeorge. 1988. Danger and Survival: Choices about the Bomb in the First Fifty Years. New York: Random House.

Burke, Jason. 2010. "Mumbai Spy Says He Worked for Terrorists then Briefed Pakistan: David Headley Helped Lakshar-E-Taiba Prepare Its Bloody Raid on Indian Soil While, He Says, Reporting to the ISI as It Fought to Retain 'Ownership' of the Group." The Guardian, October 19.

Byman, Daniel, and Matthew Waxman. 2003. The Dynamics of Coercion: American Foreign Policy and the Limits of Military Might. New York: Cambridge University Press.

Cha, Victor. 2013. The Impossible State: North Korea, Past and Future. New York: Harper Collins.

Cohen, Michael D. 2013. When Proliferation Causes Peace: Leaders and the Psychology of Nuclear Learning. Book Manuscript.

Cold War International History Project. 2012. “The Global Cuban Missile Crisis at 50." CWIHP Bulletin 17-18. http://www.wilsoncenter.org/sites/default/files/CWHIP_ Bulletin_17-18_Cuban_Missile_Crisis_v2_COMPLETE.pdf (accessed October 22, 2013).

Cousins, Norman. 1972. The Improbable Triumvirate: John F. Kennedy, Pope John, Nikita Khrushchev. New York: Norton.

Damasio, Antonio R. 1996. Descartes' Error: Emotion, Reason, and the Human Brain. New York: Putnam and Sons.

Dudley, Richard. 2013. "US Reinforcing Pacific Defenses to Counter North Korean Threats." Defense-Update, April 6. http://defense-update.com/20130406_usreinforcing-pacific-defenses-to-counter-north-korean-threats.html (accessed October 28, 2013).

Dobbs, Michael. 2009. One Minute to Midnight: Kennedy, Khrushchev and Castro on the Brink of Nuclear War. New York: Vintage Books.

Feaver, Peter D. 1995. "Optimists, Pessimists, and Theories of Nuclear Proliferation Management." Security Studies 4 (4): 754-72.

Fuhrmann, Matthew. 2012. Atomic Assistance: How 'Atoms for Peace' Programs Cause Nuclear Insecurity. Ithaca: Cornell University Press.

Fursenko, Alexsandr, and Timothy Naftali. 1998. One Hell of a Gamble: Khrushchev, Castro and Kennedy, 1958-1964. New York: Norton.

Fursenko, Alexsandr, and Timothy Naftali. 2007. Khrushchev's Cold War. New York: Norton.

Gartzke, Erik, and Dong Joon Jo. 2009. "Bargaining, Nuclear Proliferation and Interstate Disputes.” Journal of Conflict Resolution 53 (2): 209-33.

Gartzke, Erik. 2010. "Nuclear Proliferation Dynamics and Conventional Conflict." http:// dss.ucsd.edu/ egartzke/papers/nuketime_05032010.pdf (accessed October 28, 2013).

Horowitz, Michael. 2009. “The Spread of Nuclear Weapons and International Conflict: Does Experience Matter?” Journal of Conflict Resolution 53 (2): 234-57.

Hymans, Jacques E. C. 2006. The Psychology of Nuclear Proliferation: Identity, Emotions, and Foreign Policy. Cambridge: Cambridge University Press.

Jervis, Robert. 1976. Perception and Misperception in International Politics. New Jersey: Princeton University Press.

Jervis, Robert. 1978. “Cooperation under the Security Dilemma.” World Politics 30 (2): 167 - 
214.

Jervis, Robert. 1989. The Meaning of the Nuclear Revolution. Ithaca: Cornell University Press.

Jervis, Robert. 2009. “Unipolarity: A Structural Perspective." World Politics 61 (1): 188-213.

Johnson, Dominic D. P., and Dominic Tierney. 2011. "The Rubicon Theory of War: How the Path to Conflict Reaches the Point of No Return." International Security 36 (1): 7-40.

Kapur, S. Paul. 2007. Dangerous Deterrent: Nuclear Weapons Proliferation and Conflict in South Asia. Stanford: Stanford University Press.

Kapur, S. Paul. 2008. “Ten Years of Instability in Nuclear South Asia." International Security 33 (2): 71-94.

Karl, David J. 1997. "Proliferation Pessimism and Emerging Nuclear Powers." International Security 21: 87-119.

Khong, Yuen Foong. 1992. Analogies at War. New Jersey: Princeton University Press.

Kim, Eun-jung. 2013. "S. Korean Defense Chief Says 2015 OPCON Transfer 'Inappropriate."' Yonhap News, October 8.

Kroenig, Matthew. 2010. Exporting the Bomb: Technology Transfer and the Spread of Nuclear Weapons. Ithaca: Cornell University Press.

Kuisong, Yang. 2000. "The Sino-Soviet Border Clash of 1969: From Zhenbao Island to Sino-American Rapprochement." Cold War History 1: 21-51.

Lee, Chi-Dong. 2013. "Korean, U.S. Presidential Aides to Discuss OPCON, Missile Defense." Yonhap News, October 23.

Lee, Chan Jean, and Eduardo Andrade. 2011. "Fear, Social Projection and Financial Decision Making." Journal of Marketing Research 48 (November): 121-29.

Lerner, Jennifer, and Dacher Keltner. 2000. "Beyond Valence: Toward a Model of EmotionSpecific Influences on Judgment and Choice." Cognition and Emotion 14: 473-93.

Lerner, Jennifer, and Dacher Keltner. 2001. "Fear, Anger and Risk." Journal of Personality and Social Psychology 81 (1): 146-59.

Lerner, Jennifer, Roxana M. Gonzalez, Deborah A. Small, and Baruch Fischhoff. 2003. "Effects of Fear and Anger on Perceived Risks of Terrorism: A National Field Experiment." Psychological Science 14: 144-50.

Lewis, John Wilson, and Xue Litai. 2008. Imagined Enemies: China Prepares for Uncertain War. Stanford: Stanford University Press.

McDermott, Rose. 2004. "The Feeling of Rationality: The Meaning of Neuroscientific Advances for Political Science." Perspectives on Politics 2 (4): 691-706.

Mearsheimer, John J. 2001. The Tragedy of Great Power Politics. New York: Norton.

Mercer, Jonathan. 1996. Reputation and International Politics. Ithaca: Cornell University Press.

Montgomery, Alexander H., and Scott D. Sagan. 2009. “The Perils of Predicting Proliferation." Journal of Conflict Resolution 53 (2): 320-28.

Reiter, Dan. 1996. Crucible of Beliefs: Learning, Alliances and World Wars. Ithaca: Cornell University Press.

Rosen, Stephen P. 2005. War and Human Nature. New Jersey: Princeton University Press.

Sagan, Scott D., and Kenneth N. Waltz. 2013. The Spread of Nuclear Weapons: An Enduring Debate. New York: Norton.

Schelling, Thomas. 1966. Arms and Influence. New Haven: Yale University Press. 
Sechser, Todd S., and Matthew Fuhrmann. 2013. "Crisis Bargaining and Nuclear Blackmail." International Organization 67 (1): 173-95.

Smith, Craig A., and Phoebe C. Ellsworth. 1985. "Patterns of Cognitive Appraisal in Emotion." Journal of Personality and Social Psychology 48: 813-38.

Snyder, Glenn H. 1965. “The Balance of Power and the Balance of Terror." In Balance of Power, ed. Paul Seabury. San Francisco: Chandler, 184-201.

Solingen, Etel. 2006. Nuclear Logics: Contrasting Paths in East Asia and the Middle East. New Jersey: Princeton University Press.

Tang, Shiping. 2008. "Fear in International Politics: Two Positions." International Studies Review 10 (3): 451-71.

Taubman, William. 2003. Khrushchev. New York: Norton.

Tellis, Ashley, Robert D. Blackwill, Peter Chalk, Kim Cragin, C. Christine Fair, Brian A. Jackson, Brian Michael Jenkins, Seth G. Jones, Nathaniel Shestak, and Angel Rabasa. 2009. "The Lessons of Mumbai." RAND Occasional Paper. http://www.rand.org/ content/dam/rand/pubs/occasional_papers/2009/RAND_OP249.pdf (accessed October 28, 2013).

Thucydides. 1954 [c431BC]. The Peloponnesian War. Trans. Rex Warner. London: Penguin. Tooby, John, and Leda Cosmides. 2010. "The Evolutionary Psychology of the Emotions and Their Relationship to Internal Regulatory Variables." In Handbook of the Emotions, 3rd ed., eds. Michael Lewis, Jeannette M. Haviland-Jones, and Lisa Feldman Barrett. New York: Guilford, 114-37.

Waltz, Kenneth N. 1990. "Nuclear Myths and Political Realities." American Political Science Review 84 (3): 731-45.

Waltz, Kenneth N. 2003. "Waltz Responds to Sagan." In The Spread of Nuclear Weapons: A Debate Renewed, eds. Kenneth N. Waltz, and Scott D. Sagan. New York: Norton, 82111.

Yonhap News. 2013. "Park Pledges Strong Defense to Render N. Korean Nukes Useless." October 1.

Michael D. Cohen is Assistant Professor in the Department of Political Science at the University of Southern Denmark. His research has been published in the journal International Security and the Non-Proliferation Review and a Stanford University Press edited volume, and has been funded by the Lyndon B. Johnson Foundation, the Simons Foundation and numerous awards from the University of British Columbia and the University of Southern Denmark. He blogs at the Global Policy Journal and has published in newspapers such as The Australian Financial Review and Berlingske. 
